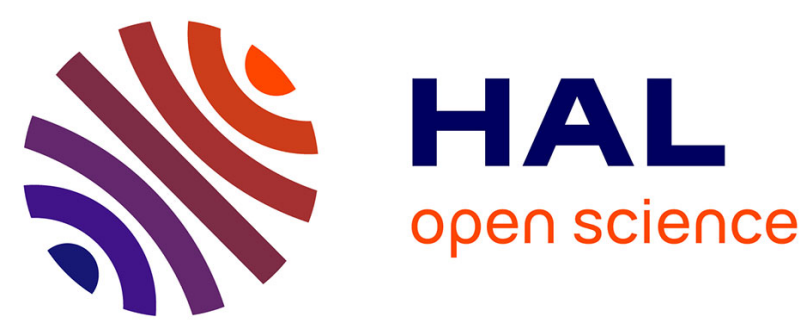

\title{
Development status of triple-junction solar cells optimized for low intensity low temperature applications
} C. Baur, V. Khorenko, G. Siefer, J.C. Bourgoin, M. Casale, R. Campesato, S. Duzellier, V. Inguimbert

\section{- To cite this version:}

C. Baur, V. Khorenko, G. Siefer, J.C. Bourgoin, M. Casale, et al.. Development status of triplejunction solar cells optimized for low intensity low temperature applications. 39th IEEE Photovoltaic Specialists Conference (PVSC), Jun 2013, TAMPA, United States. hal-01057758

HAL Id: hal-01057758

https: / hal-onera.archives-ouvertes.fr/hal-01057758

Submitted on 25 Aug 2014

HAL is a multi-disciplinary open access archive for the deposit and dissemination of scientific research documents, whether they are published or not. The documents may come from teaching and research institutions in France or abroad, or from public or private research centers.
L'archive ouverte pluridisciplinaire HAL, est destinée au dépôt et à la diffusion de documents scientifiques de niveau recherche, publiés ou non, émanant des établissements d'enseignement et de recherche français ou étrangers, des laboratoires publics ou privés. 


\title{
Development status of triple-junction solar cells optimized for low intensity low temperature applications
}

\author{
Carsten Baur ${ }^{1}$, Victor Khorenko ${ }^{2}$, Gerald Siefer ${ }^{3}$, Jacques C. Bourgoin ${ }^{4}$, Mariacristina Casale ${ }^{5}$, Roberta \\ Campesato $^{5}$, Sophie Duzellier ${ }^{6}$, and Virginie Inguimbert ${ }^{6}$
}

\author{
${ }^{1}$ European Space Agency, Noordwijk, 2201AZ, The Netherlands, ${ }^{2}$ AZUR SPACE Solar Power GmbH, \\ Heilbronn, 74072, Germany, ${ }^{3}$ Fraunhofer Institute for Solar Energy Systems, Freiburg, 79110, Germany, \\ ${ }^{4}$ GESEC R\&D Inc., Thomery, 77810, France, ${ }^{5}$ CESI S.p.A., Milan, 20134, Italy, ${ }^{6}$ ONERA/DESP, Toulouse \\ Cédex 4, 31055, France
}

\begin{abstract}
Latest results of $3 \mathrm{G} 28$ triple-junction solar cells manufactured by AZUR SPACE Solar Power GmbH under low intensity low temperature (LILT) conditions are reported. Excellent beginning of life efficiencies (BOL) in the order of $35 \%$ at $50 \mathrm{~W} / \mathrm{m}^{2}$ and $-150^{\circ} \mathrm{C}$ have been realized on a large number of cells with standard and LILT optimized design. Furthermore, temperature dependent irradiation tests with $1 \mathrm{MeV}$ electrons and $1 \mathrm{MeV}$ protons have been performed on LILT optimized $3 G 28$ solar cells. Initial results show some indications of temperature annealing but also other annealing or stabilization effects already present at LILT conditions.
\end{abstract}

Index Terms - III-V semiconductor materials, Jupiter, photovoltaic cells, temperature dependence, radiation effects.

\section{INTRODUCTION}

Solar cells are the obvious choice to be used as the primary energy source on satellites and spacecrafts for almost any mission lasting longer than a few days and with a maximum distance of up to 5 Astronomical Units (AU) around the sun. Thus, missions to Jupiter (5.2 AU) represent the limit of the feasibility of photovoltaics due to the very low solar intensities $\left(45-50 \mathrm{~W} / \mathrm{m}^{2}\right.$ compared to $1370 \mathrm{~W} / \mathrm{m}^{2}$ around Earth).

Apart from the low solar intensities the solar cells operate also at very low temperatures (around $-150^{\circ} \mathrm{C}$ ). A combination of low solar intensity and low temperature represents also typical conditions around Jupiter and is frequently also referred to as "LILT" conditions. Unless stated otherwise LILT conditions shall be understood as 3.7\% AM0 sun intensity and $-150^{\circ} \mathrm{C}$.

Although low temperatures are typically improving solar cell efficiencies, other effects not present at room temperatures can limit the performance of the solar cells with the so-called "flat spot effect" being the most detrimental [1, $2,3]$. In contrast to a "normal" shunt that can be easily detected under room temperature conditions the flat spot effect is only observed at low temperatures which also does not allow for a screening only based on room temperature measurements. An example of a the flat spot effect is shown in Fig. 1. Obviously the flat spot effect results in a non-ideal I$\mathrm{V}$ characteristic close to the maximum power point of the solar cell. In addition, the effect can vary quite strongly from cell to cell which for a given solar cell design that is prone to show the flat spot effect results in a very unpredictable LILT performance making it basically unusable for deep space missions.

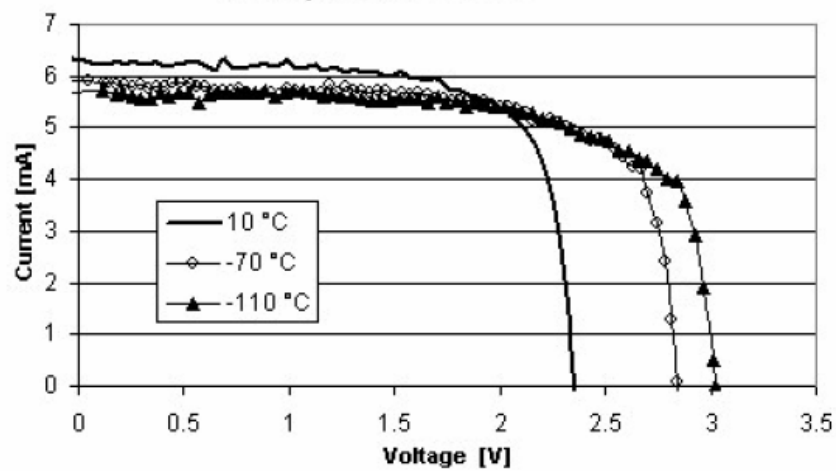

Fig. 1: Example of a flat spot effect present in a triplejunction solar cell from CESI. The graph has been taken from [3].

Starting in 2005 dedicated R\&D activities have been initiated by ESA aiming at both, understanding of potential limitations of standard triple-junction solar cell technologies at LILT conditions (both, at beginning of life - BOL - and end of life - EOL) as well as modifying and/or developing (if applicable) solar cell structures that would perform in a well predictable way under LILT conditions, i.e. would not show any flat spot effects. Special emphasis was put also on the degradation behavior of the solar cells due to particle irradiation under LILT conditions which basically translates into the questions whether there are any annealing effects that need to be considered and whether the defect introduction rate of the incident particles when interacting with the crystal atoms is temperature dependent.

Finally, appropriate selection criteria based on room temperature measurements are requested which are able to identify all solar cells that would show a poor performance at LILT conditions.

In this paper we update on the latest results that were obtained in the most recent activity dedicated to the design 
optimization of solar cells for LILT applications and their characterization in a representative environment around Jupiter.

\section{EXPERIMENT}

In all previous and current ESA funded R\&D activities related to the establishment of a solar cell for deep space missions usable up to a distance as far from the sun as Jupiter the baseline solar cell design was always the lattice-matched triple-junction solar cell 3G28 from AZUR SPACE based on the material combination $\mathrm{GaInP} / \mathrm{GaInAs} / \mathrm{Ge}$. This cell is qualified for GEO and LEO missions and has already significant flight heritage in corresponding environments.

However, in a precursor activity it was found that small modifications in the cell technology of the $3 \mathrm{G} 28$ solar cell have beneficial effects on the predictability of the solar cell performance under LILT conditions [4]. A change of the front side metallization together with the application of a passivation layer protecting the cell edges resulted in superior LILT efficiencies compared to those obtained with standard 3G28 technology. Furthermore, no signs of flat spot effects were observed with the modified design turning it into a perfect candidate to become the baseline option for deep space missions up to around Jupiter. However, these initial results were obtained on a quite small sample basis and only using $2 \times 2 \mathrm{~cm}^{2}$ cells.

Thus, these findings had to be verified by more comprehensive testing following more closely the ECSS (European Cooperation for Space Standardization) philosophy. Therefore, about $1503 \mathrm{G} 28$ solar cells with modified cell technology (front side metallization and edge passivation - in the following referred to as "LILT design") and a standard area of $4 \times 8 \mathrm{~cm}^{2}$ (with cropped corners) have been manufactured. As a backup the same amount of $3 \mathrm{G} 28$ standard cells have been manufactured.

On bare cell level the cells were submitted to an acceptance/screening test sequence consisting of the following measurements performed at AZUR SPACE:

- Dark I-V (at $25^{\circ} \mathrm{C}$ and at $-196^{\circ} \mathrm{C}$ in liquid nitrogen atmosphere)

- Light I-V under AM0, 3.7\% AM0 and 3.7\% AM0 + "blue boost" to make the middle cell current limiting

Screening and acceptance tests are aimed solely for sorting out solar cells that show low shunt resistances. It was not considered to detect cells that are prone to show the flat spot effect at LILT conditions since earlier studies already showed that flat spot effects can only be detected under low temperatures [3].

The cells were then processed into solar cell assemblies (SCA), i.e. Ag interconnectors were welded on the front side and a CMX coverglass by Qioptiq was glued on top. These SCAs were then submitted to a BOL characterization test sequence. The test plan for solar cells and SCAs is given in Table I. The high temperature step after step 11 on part of the SCAs was introduced to simulate a potential Venus fly-by.

TABLE I

TEST PLAN FOR $4 \mathrm{X} 8 \mathrm{CM}^{2}$ CELLS AND SCAS WITH STANDARD AND MODIFIED DESIGN.

\begin{tabular}{|c|c|c|}
\hline & Test & Conditions \\
\hline 1 & Visual inspection & \\
\hline 2 & Interconnector welding & \\
\hline 3 & Humidity and temperature (HT) & $\begin{array}{l}90 \% \text { rel. humidity at } 95^{\circ} \mathrm{C} \\
\text { for } 24 \mathrm{~h}\end{array}$ \\
\hline 4 & Coating adherence (tape peel test) & After HT test \\
\hline 5 & $\begin{array}{l}\text { Pull tests after front / back side } \\
\text { interconnect welding }\end{array}$ & $\begin{array}{l}\text { After } \mathrm{HT} \text { test with } \mathrm{Ag} \\
\text { interconnectors }\end{array}$ \\
\hline 6 & Dark IV & $25^{\circ} \mathrm{C}$ \\
\hline 7 & $\begin{array}{l}\text { El. performance at room } \\
\text { temperature (RT) }\end{array}$ & $\mathrm{AM} 0,25^{\circ} \mathrm{C}$ \\
\hline 8 & $\begin{array}{l}\text { El. performance at low intensity and } \\
\text { room temperature (LIRT) }\end{array}$ & $0.037 \mathrm{AM} 0,25^{\circ} \mathrm{C}$ \\
\hline 9 & Electroluminescence (EL) mapping & $25^{\circ} \mathrm{C}$ \\
\hline 10 & Dark IV & $-195^{\circ} \mathrm{C}$ \\
\hline \multicolumn{3}{|c|}{ SCA Manufacturing } \\
\hline 11 & Visual inspection & \\
\hline \multicolumn{3}{|c|}{ High temperature step $\left(100^{\circ} \mathrm{C}\right.$ for $\left.72 \mathrm{~h}\right)$ on $50 \%$ of the SCAs } \\
\hline 12 & Dark IV & $25^{\circ} \mathrm{C}$ \\
\hline 13 & El. performance at RT & $\mathrm{AM0}, 25^{\circ} \mathrm{C}$ \\
\hline 14 & El. performance at LIRT & $0.037 \mathrm{AMO}, 25^{\circ} \mathrm{C}$ \\
\hline 15 & EL mapping & $25^{\circ} \mathrm{C}$ \\
\hline 16 & Dark IV & $-195^{\circ} \mathrm{C}$ \\
\hline 17 & $\begin{array}{l}\text { El. performance at various } \\
\text { temperatures }\end{array}$ & $\begin{array}{c}\mathrm{AM} 0,25^{\circ} \mathrm{C},-40^{\circ} \mathrm{C}, \\
-80^{\circ} \mathrm{C},-120^{\circ} \mathrm{C},-150^{\circ} \mathrm{C}\end{array}$ \\
\hline 18 & $\begin{array}{l}\text { El. performance at various } \\
\text { temperatures }\end{array}$ & $\begin{array}{c}0.037 \mathrm{AM} 0,25^{\circ} \mathrm{C} \\
-40^{\circ} \mathrm{C},-80^{\circ} \mathrm{C} \\
-120^{\circ} \mathrm{C},-150^{\circ} \mathrm{C}\end{array}$ \\
\hline
\end{tabular}

The different tasks given in Table I were carried out by AZUR SPACE (1-16) and CESI (17+18).

In addition to the $4 \times 8 \mathrm{~cm}^{2}$ cells also $2 \times 2 \mathrm{~cm}^{2}$ triple-junction and component cells were manufactured, however, with the modified design only. Component cells are single-junction solar cells with the same layer structure as the corresponding triple-junction solar cell but with only one p-n junction, i.e. only one subcell being active. The $2 \times 2 \mathrm{~cm}^{2}$ dedicated to electron and proton irradiation testing were submitted to the same screening tests described above.

Full BOL and EOL characterization of the $2 \times 2 \mathrm{~cm}^{2}$ cells was then performed by the Fraunhofer ISE. The characterization included temperature dependent light I-V measurements in line with steps 17 and 18 (Table I) but in addition also temperature dependent dark $\mathrm{I}-\mathrm{V}$ and spectral response measurements were performed.

Proton and electron irradiation tests were performed at room temperature and low temperature with in-situ characterization after each irradiation step and a dedicated test sequence that should reveal any annealing effects (for the low temperature irradiation tests).

Proton irradiation testing was carried out by GESEC using the facilities of CSNSM (Centre de Spectrométrie Nucléaire et 
de Spectrométrie de Masse) close to Paris. Electron irradiation tests were performed at ONERA in Toulouse again with support from GESEC.

Each irradiation test consisted of 3 irradiation steps with insitu dark and light I-V characterization after each step. A schematic of the test setup that was used for all irradiation tests is shown in Fig. 2. Main features of the setup are the cryostat consisting of a turnable head allowing for irradiation from one side and illumination by a two source simulator (Xenon and quartz tungsten halogen lamp) from another side without breaking the vacuum or changing the temperature.

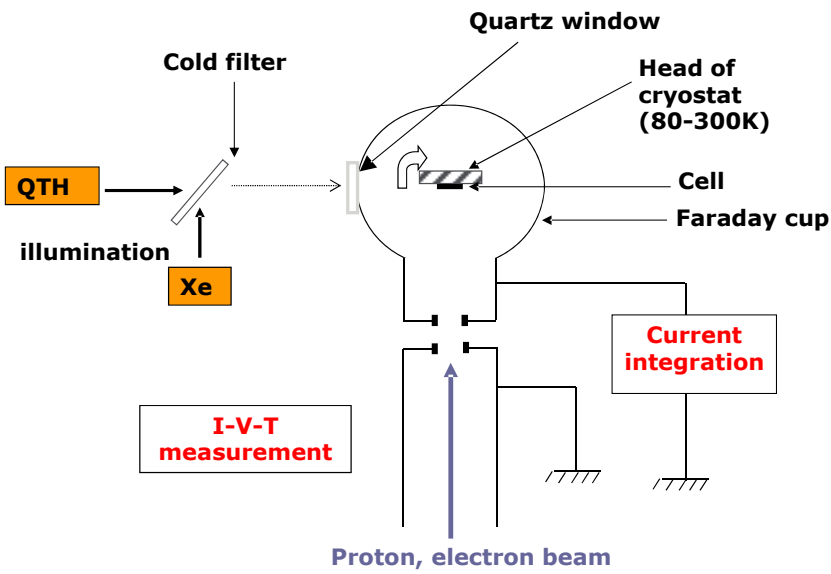

Fig. 2. Schematic of the test setup used for low temperature irradiation and in-situ light I-V measurements.

The test sequence carried out for the low temperature irradiation test is given in Table II.

TABLE II

TEST SEQUENCE CARRIED OUT ON SOLAR CELLS THAT WERE SUBMITTED TO LOW TEMPERATURE IRRADIATION TESTING.

\begin{tabular}{|c|c|c|}
\hline & Test & Conditions \\
\hline \hline 1 & light I-V, dark I-V & $0.037 \mathrm{AMO}, 25^{\circ} \mathrm{C}$ \\
\hline 2 & light I-V, dark I-V & $0.037 \mathrm{AM} 0,-150^{\circ} \mathrm{C}$ \\
\hline $1+2 \mathrm{n}$ & $\mathrm{n}^{\mathrm{h}}$ irradiation step & $-150^{\circ} \mathrm{C}$ \\
\hline $2+2 \mathrm{n}$ & light I-V, dark I-V & $0.037 \mathrm{AMO},-150^{\circ} \mathrm{C}$ \\
\hline \multicolumn{3}{|c|}{ Repeat above steps for $\mathrm{n}=1,2,3$} \\
\hline 9 & light I-V, dark I-V & $0.037 \mathrm{AM0}, 25^{\circ} \mathrm{C}$ \\
\hline 10 & light I-V, dark I-V & $0.037 \mathrm{AM},-150^{\circ} \mathrm{C}$ \\
\hline 11 & light I-V, dark I-V & $0.037 \mathrm{AM} 0,25^{\circ} \mathrm{C}$ \\
\hline
\end{tabular}

\section{RESULTS}

\section{A. BOL results}

Fig. 3 shows exemplarily I-V characteristics of a $4 \times 8 \mathrm{~cm}^{2}$ SCA measured by CESI under low intensity (3.7\% AM0) at various temperatures. When plotting the open circuit voltage $\left(\mathrm{V}_{\mathrm{OC}}\right)$ vs. temperature a perfect linear relationship is observed as theoretically expected. Values in the order of $3.5 \mathrm{~V}$ are obtained at LILT conditions. The temperature coefficient derived by performing a linear fit of a representative subset of all SCAs involved in this measurement campaign including cells from both designs - standard and LILT design (cp. Fig. 4) - results in a value of $-6 \mathrm{mV} / \mathrm{K}$ which is almost identical to the temperature coefficient under AM0 conditions.

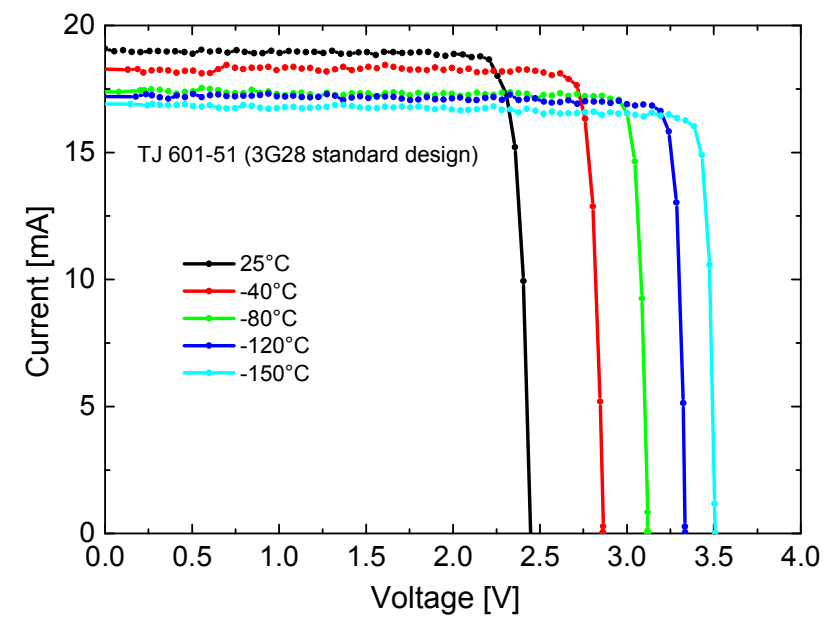

Fig. 3. Example of temperature dependent I-V measurements under low intensity (3.7\% AM0) of an average performing $3 \mathrm{G} 28$ solar cell with standard design.

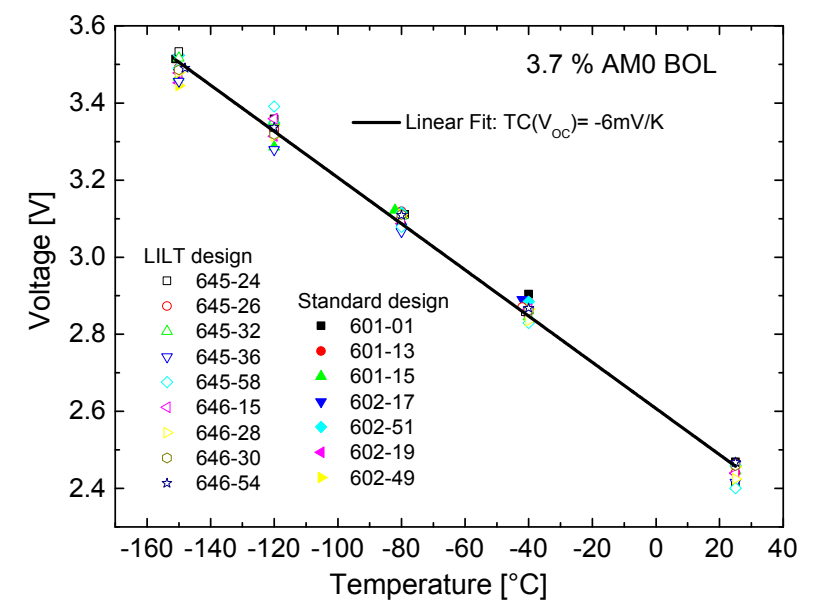

Fig. 4. $\mathrm{V}_{\mathrm{OC}}$ vs temperature for a representative subset of the SCAs with solar cells from both, the standard and LILT design.

Another important parameter to be checked when performing measurements at very low temperatures is the fill factor (FF). Fig. 5 shows that the fill factor increases with decreasing temperature. This is also expected due to the fact that the dark currents in the cell become smaller with decreasing temperatures and thus the curve tends to become more rectangular (cp. Also Fig. 3). However, in contrast to the $\mathrm{V}_{\mathrm{OC}}$ the FF for most of the SCAs either saturates or it peaks at around $-120^{\circ} \mathrm{C}$ and decreases again slightly for even lower temperatures still remaining at quite high values of equal or greater than $90 \%$.

The effect of saturation or slight decrease in FF can be explained by tunneling currents (see e.g. [5]) which are at typical operating conditions $\left(>60^{\circ} \mathrm{C}\right)$ orders of magnitude 
smaller compared to the dark saturation currents in the bulk material and the recombination currents in the space charge region. However, at very low temperatures the dark saturation and recombination currents are reduced to values which are of the same order as the tunnel currents and thus the tunnel currents start to have a non-negligible influence on the solar cell performance close to the maximum power point.

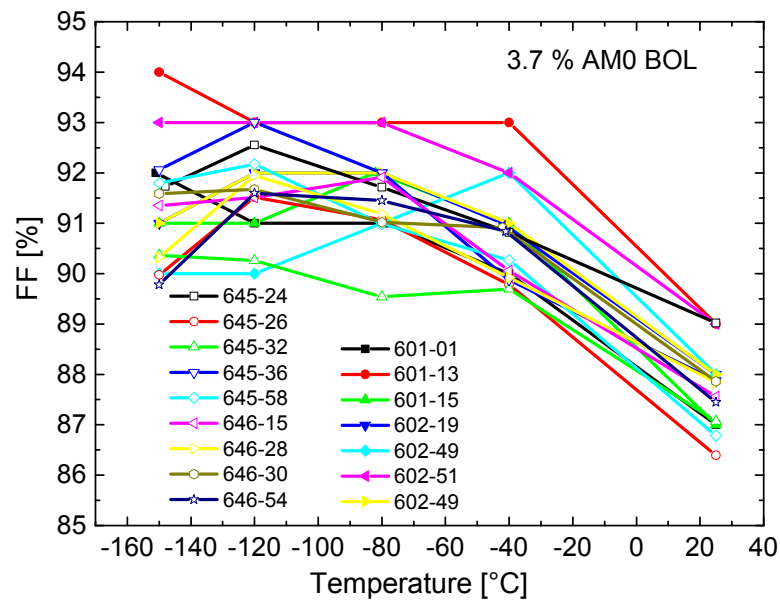

Fig. 5. FF vs temperature for a representative subset of the SCAs with solar cells from both, the standard and LILT design.

Fig. 6 provides now an overview of the efficiency evolution vs. temperature at low intensity for all SCAs using cells with the LILT design. It should be mentioned that no difference in performance was observed for SCAs that were submitted to the additional high temperature step.

At $-120^{\circ} \mathrm{C}$ and $-150^{\circ} \mathrm{C}$ a few outliers can be observed with efficiencies lower than $32 \%$. These cells would have been successfully sorted out by the applied screening test since these cells showed already shunts at room temperatures. None of the SCAs has shown a flat spot effect.

Table IV summarizes the BOL results obtained on SCA level for both the standard and the LILT design of the 3G28 solar cell from AZUR SPACE (excluding cells that would have been sorted out). Average efficiencies of around 35\% at LILT conditions as obtained in this test campaign are fully in line with theoretical considerations when any detrimental effects such as the flat spot effect can be neglected.

The standard 3G28 solar cell performs slightly better than the cell with LILT design but which is still within the manufacturing tolerance. However, at LILT conditions the cells with the LILT design show a narrower distribution.

Thus, irradiation testing on $2 \times 2 \mathrm{~cm}^{2}$ cells has been carried out on bare cells with LILT design only. In the course of the BOL characterization on these cells performed by the Fraunhofer ISE the results obtained on SCA level have been confirmed, i.e. LILT efficiencies of around $35 \%$ and no observation of flat spot effects.
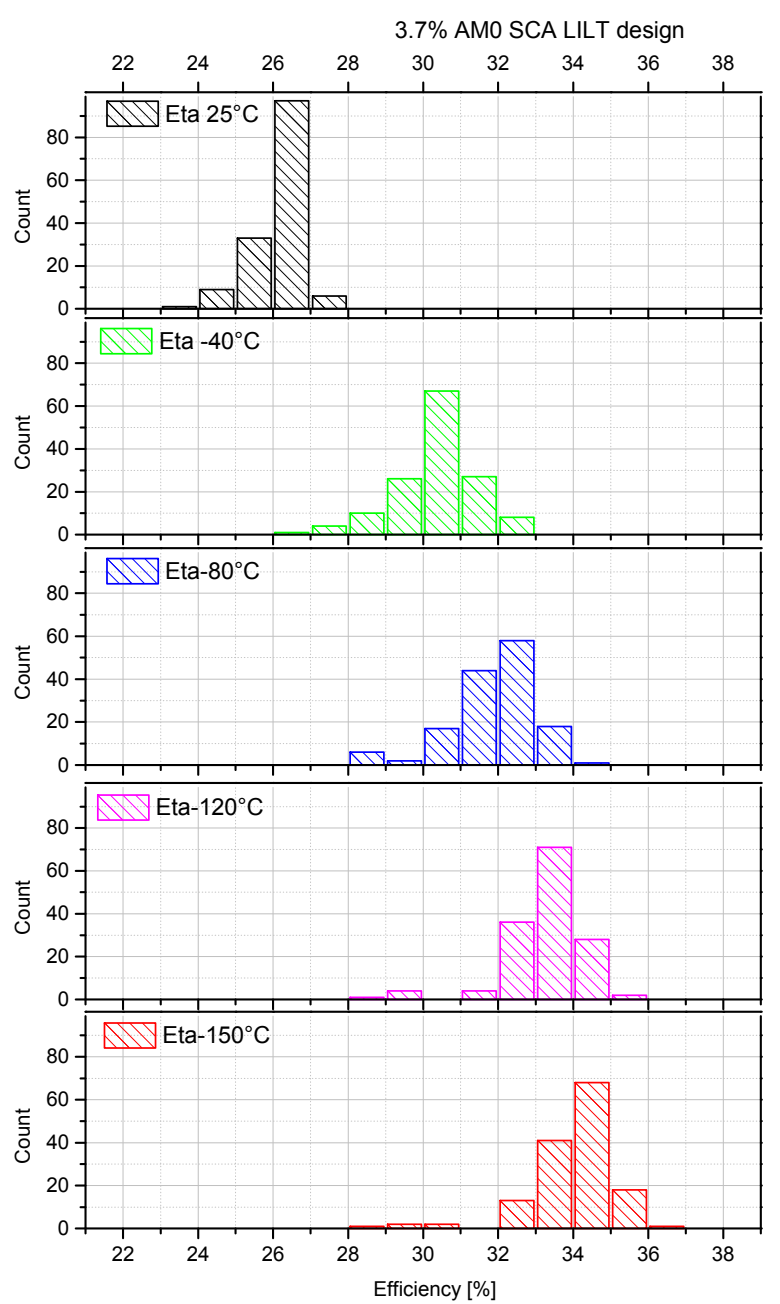

Fig. 6: Distribution of efficiency values of SCAs of the LILT design measured under $3.7 \% \mathrm{AM} 0$ and different temperatures.

TABLE IV

BOL CHARACTERIZATION RESULTS OF MORE THAN 100 SCAS EACH WITH STANDARD AND MODIFIED DESIGN. VALUES ARE GIVEN FOR $0.037 \mathrm{AM} 0$ AND $-150^{\circ} \mathrm{C}$.

\begin{tabular}{|l|c|c|c|c|c|}
\hline Design & $\begin{array}{c}\text { No. } \\
\text { cells }\end{array}$ & Mean eff. & Std dev. & Min eff. & Max eff. \\
\hline \hline Standard & 110 & $35.8 \%$ & $0.9 \%$ & $33.4 \%$ & $38.1 \%$ \\
\hline LILT & 133 & $34.2 \%$ & $0.8 \%$ & $32.2 \%$ & $36.4 \%$ \\
\hline
\end{tabular}

\section{B. EOL (post irradiation) results}

Apart from the demand to understand the degradation curve of the 3G28 solar cell under LILT conditions the main objective of the performed irradiation tests was to understand whether annealing effects can be observed and whether there is a temperature dependent defect introduction rate. Both effects could in principle be expected.

With respect to the defect introduction rate at temperature dependence could originate from the fact that the defect introduction rate is proportional to the potentially temperature 
dependent cross section between the incident particle and the target atom in the crystal.

Annealing effects, i.e. the annihilation of defects which have been created during the irradiation experiment, have been observed and reported also elsewhere and are commonly understood to be thermally activated [6].

Obviously, in case significant temperature dependent effects in the context of particle irradiation experiments would be observed, certainly a quite substantial effort would be required to quantify these effects during or prior a qualification campaign for a deep space mission.

First results in the past suggested that for the $3 \mathrm{G} 28$ solar cells there are neither significant annealing effects nor temperature dependent defect introduction rates to be taken into account [7]. However, due to the importance of this point, additional low temperature irradiation experiments have been carried out to verify these earlier findings. In the following only results from the electron irradiation experiments are presented. Analogue results were obtained from the proton irradiation tests.

Fig. 7 and also Fig. 8 summarize the findings with respect to the potential temperature dependence of the defect introduction rate. Fig. 7 shows I-V curves under low intensity of two triple-junction cells TJ97 and TJ85 BOL and EOL. While TJ97 has been irradiated at room temperature TJ85 has been irradiated at $-150^{\circ} \mathrm{C}$. As shown in the graph both cells have an almost identical performance at BOL (black and red curves). Also at EOL (after irradiation with $1 \mathrm{MeV}$ electrons up to a fluence of $2 \mathrm{E} 15 \mathrm{~cm}^{-2}$ ) the performance at room temperature of both cells is identical. Only at low temperature TJ85 provides a slightly higher voltage compared to TJ97. .

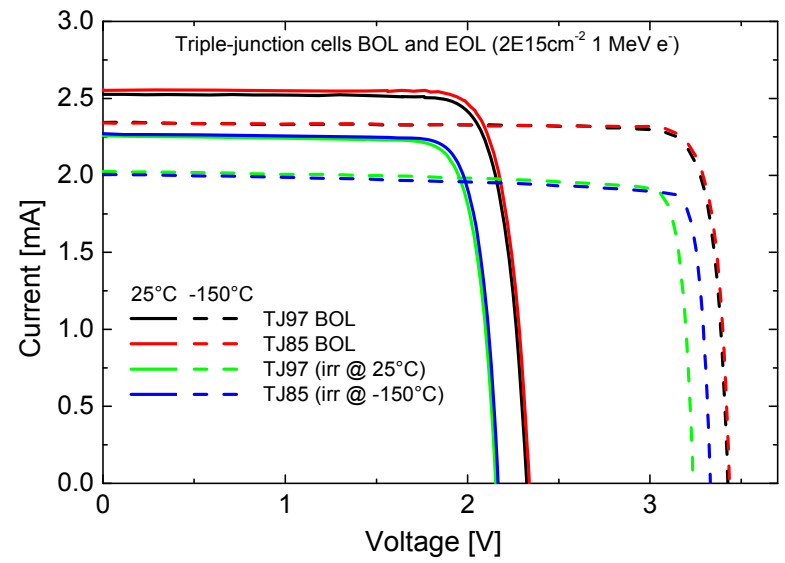

Fig. 7: I-V curves under 3.7\% AM0 of TJ cells 97 and $85 \mathrm{BOL}$ and EOL measured at $25^{\circ} \mathrm{C}$ and $-150^{\circ} \mathrm{C}$. While TJ97 has been irradiated at room temperature $\mathrm{TJ} 85$ has been irradiated at $-150^{\circ} \mathrm{C}$.

Fig. 8 shows external quantum efficiency (EQE) measurements of the top and middle subcell of the same two triple-junction cells after irradiation measured at $25^{\circ} \mathrm{C}$ and $-150^{\circ} \mathrm{C}$. Also here almost no difference is observed in the cells after irradiation backing up the findings from the I-V measurements. Note that also in the bottom subcell EQE (not shown here) no differences are present.

Thus, one can conclude that the defect introduction rates at room temperature and low temperature are almost identical. This statement still holds when annealing effects would be detected since both cells were given significant time to stabilize, i.e. in case of any temperature annealing both cells were kept long enough at the same room temperature conditions so that any annealing processes that could have taken place in both cells during this time can be considered to have resulted in the same performance improvement. Note that the measurements shown in Fig. 7 and 8 have been carried out around six months after the irradiation experiment was finished.

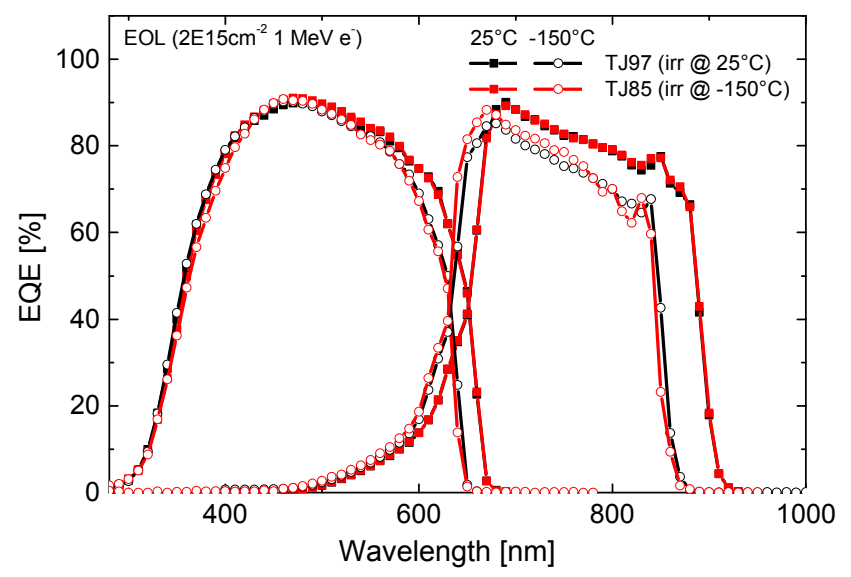

Fig. 8: Top and middle cell EQE of TJ cells 97 and 85 after electron irradiation measured at $25^{\circ} \mathrm{C}$ and $-150^{\circ} \mathrm{C}$. While TJ97 has been irradiated at room temperature $\mathrm{TJ} 85$ has been irradiated at $-150^{\circ} \mathrm{C}$.

With respect to potential annealing effects after low temperature irradiation and subsequent warm up to room temperature the situation is however not that clear.

Fig. 9 shows the degradation behavior of the maximum power point $\mathrm{P}_{\mathrm{MPP}}$ of triple-junction cell TJ85 at low temperature vs. electron irradiation. After each of the irradiation steps two I-V curve measurements have been performed. The black squares in Fig. 9 represent the first measurement while the red squares give the values of the second measurement. Note that these measurements are performed in-situ keeping the sample always at $-150^{\circ} \mathrm{C}$. Also the illumination conditions were always limited to $3.7 \%$ AM0. The repetition of the I-V curve measurement was initially only done for statistical reasons and to improve the confidence in the measurement. However, unexpectedly a consistent trend was observed in all measurements performed on triplejunction cells that were irradiated at low temperatures pointing in the direction of a stabilization of the cells already at low temperatures without an additional high temperature step. Corresponding irradiation tests performed on component cell level revealed that also the bottom cell shows a similar performance improvement with time after particle irradiation 
at low temperature (without a heating step). Thus, one could argue that the stabilization effects observed in the triplejunction are related to the bottom cell. However, this is in contradiction to the fact that the solar cells do not only show a performance improvement in voltage but also in current. But the current limiting top and middle subcell do not show these performance improvements at low temperatures.

After the last measurement at low temperatures and the maximum irradiation dose the cells have been submitted to a "real" temperature annealing step by warming the cells up to room temperature. The two blue circles in Fig. 9 indicate the two measurements that have been performed at LILT conditions after this annealing step. Taking into account that no further stabilization at low temperature would occur the difference between the two blue circles of around $3 \%$ could be considered to represent the repeatability of measurements under these conditions.

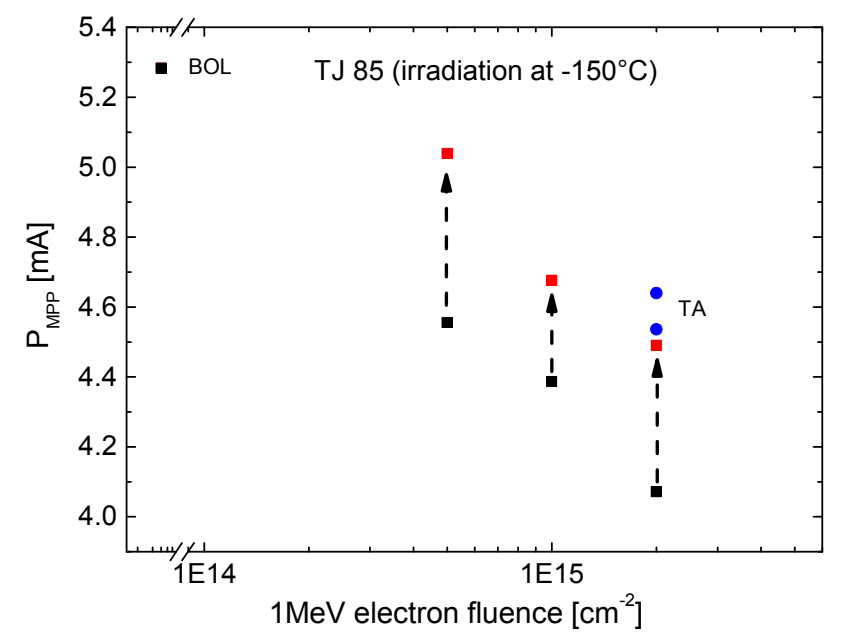

Fig. 9. $\mathrm{P}_{\max }$ vs. $1 \mathrm{MeV}$ electron fluence TJ85 under LILT conditons. After each irradiation step two I-V measurements were performed represented by the black and red symbols.

Then, the difference between the two blue symbols and the red symbol at $2 \mathrm{E} 15 \mathrm{~cm}^{-2}$ could be referred to be within the measurement uncertainty. However, in some other triplejunction cells of the same type the difference between the last measurement at low temperature before warming up the cell to room temperature and the first point after cooling down again is significantly larger and again in others there is almost no difference at all. Again, the results on component cell level only show additional temperature annealing effects to be present in the bottom cell. Top and middle component cells do not show any annealing effects.

In summary, the results on the annealing investigations on the 3G28 solar cell are not fully conclusive, yet. Therefore, additional low temperature irradiation tests will be carried out where any potential stabilization effects at low temperatures and temperature annealing effects are going to be revealed.

\section{CONCLUSION}

Most recent results on the LILT characterization of standard and LILT optimized 3G28 triple-junction solar cells and SCAs from AZUR SPACE have been presented. Outstanding efficiencies of about $35 \%$ in average for both cell designs have been measured under LILT conditions on SCA and bare cell level. No sign of the flat spot phenomenon has been observed in any of the measurements. Thus, a screening method based on room temperature measurements only, sorting out cells with low shunt resistances, could have been successfully implemented. Results after and during particle irradiation are not fully conclusive, yet. While it appears evident that the defect introduction rates at low temperature and room temperature do not show significant differences additional tests will be performed in order to understand the presence of any potential annealing effects.

\section{REFERENCES}

[1] V. G. Weizer and J. D. Broder, "On the cause of the flat-spot phenomenon observed in silicon solar cells at low temperatures and low intensities," Journal of Applied Physics, vol. 53, no. 8, pp. 5926-5930, 1982.

[2] C. J. Gelderloos, K. B. Miller, R. J. Walters, G. P. Summers, and S. R. Messenger, "Low intensity low temperature performance of advanced solar cells," in Proceedings of the 29th IEEE Photovoltaics Specialists Conference, (New Orleans, Louisiana, USA), pp. 804-807, 2002.

[3] R. Campesato, C. Flores, G. Damonte, and S. Taylor, "Modelling and analysis of multi junction solar cells at low temperature/low intensity conditions," in Proceedings of the 22nd European Photovoltaic Solar Energy Conference, (Milano, Italy), pp. 680-683, 2007.

[4] V. Khorenko, G. F. X. Strobl, R. Hoheisel, F. Dimroth, R. Campesato, M. Casale, and C. Baur, "Triple-junction solar cell design for low intensity low temperature space applications," in Proceedings of the 9th European Space Power Conference, (St. Raphael, France), 2011.

[5] J. A. Del Alamo and R. M. Swanson, "Forward-bias tunneling: a limitation to bipolar device scaling," IEEE Electron Device Letters, vol. EDL-7, no. 11, pp. 629-631, 1986.

[6] M. Imaizumi, R. D. Harris, R. J. Walters, J. R. Lorentzen, S. R. Messenger, J. G. Tischler, T. Ohshima, S. Sato, P. R. Sharps, and N. S. Fatemi, "Irradiation and measurement of solar cells at low intensity, low temperature (LILT) conditions," in Proceedings of the 33rd IEEE Photovoltaic Specialists Conference, (San Diego, California, USA), 2008.

[7] S. Taylor, C. Baur, T. Torunski, V. Khorenko, G. Strobl, R. Campesato, R. Hoheisel, M. Hermle, F. Dimroth, D. Stetter, K. Dettlaff, J. Bourgoin, S. Makham, and G. Sun, "Performance of European triple-junction solar cells for deep space missions," in Proceedings of the 8th European Space Power Conference, vol. SP-661, (Constance, Germany), ESA, 2008. 